${ }^{3}$ Maguire GP, Lee EG, Bevington DJ, Kuchemann CS, Crabtree RJ, Cornell CE. Psychiatric problems in the first year after mastectomy. Br Med F 1978;i:963-5.

${ }^{4}$ Maguire P, Tait A, Brooke M, Sellwood R. Emotional aspects of mastectomy: planning a caring programme. Nursing Mirror 1980 January $17: 35-7$.

5 Wing JK, Nixon J, Mann A, Leff JP. Reliability of the PSE (ninth edition) used in a population study. Psychol Med 1977;7:505-16.
${ }^{6}$ Brown GW, Harris T. Social origins of depression. London: Tavistock Press, 1978.

7 Maguire P, Tait A, Brooke M. Mastectomy: a conspiracy of pretence. Nursing Mirror 1980, January 10: 17-19.

${ }^{8}$ Sanson-Fisher R, Maguire P. Should skills in communicating with patients be taught in medical schools? Lancet (in press).

(Accepted 9 October 1980)

\title{
Glial origin of rapidly adhering amniotic fluid cells
}

\author{
PERTTI AULA, HARRIET VON KOSKULL, KARI TERAMO, OLAVI KARJALAINEN, \\ ISMO VIRTANEN, VELI-PEKKA LEHTO, DORIS DAHL
}

\section{Summary and conclusions}

Rapidly adhering cells (RA cells) from the amniotic fluid of a pregnancy with fetal anencephaly were investigated by immunofluorescence assay with an antiserum against glial cells. After 24 hours' cultivation a high proportion of the cells showed positive glial-specific fluorescence, whereas no staining was seen in cells from samples of normal amniotic fluid. At the 24 th week the mother was delivered of a stillborn infant with anencephaly.

Immunofluorescence staining of $R A$ cells with glialspecific antiserum may be used for the differential diagnosis of fetal abnormalities associated with a high $\alpha$-fetoprotein concentration in amniotic fluid.

\section{Introduction}

Amniotic fluid from pregnancies complicated by fetal anencephaly or spina bifida contains an excess of cells that adhere rapidly to glass or plastic under tissue-culture conditions. ${ }^{1}$ Testing for these cells has been proposed as an adjunct to $\alpha$-fetoprotein assays in the prenatal diagnosis of neural-tube defects. ${ }^{2}$ These rapidly adhering cells (RA cells) may show extensive variation in morphology, and Gosden and Brock ${ }^{3}$ classified four different types in amniotic fluid from pregnancies complicated by fetal anencephaly and spina bifida. The origin of the cells has not been proved, though their gross morphological appearances suggest that they originate from the central nervous system. ${ }^{4}$ We describe a pregnancy complicated by anencephaly in which immunofluorescence studies showed the cells to be of glial origin.

\footnotetext{
Laboratory of Prenatal Genetics, Departments I and II of Obstetrics and Gynaecology, University of Helsinki, Finland

PERTTI AULA, MD, medical geneticist

HARRIET VON KOSKULL, MSC, geneticist

KARI TERAMO, MD, senior obstetrician

OLAVI KARJALAINEN, MD, acting professor of obstetrics and gynaecology

Department of Pathology, University of Helsinki, Finland

ISMO VIRTANEN, MD, senior scientist

VELI-PEKKA LEHTO, $M D$, assistant of pathology

Department of Neuropathology, Harvard Medical School, and Spinal Cord Injury Service, West Roxbury Veterans Administration Medical Center, Boston, USA

DORIS DAHL, PHD, assistant professor of neuropathology
}

\section{Patient and methods}

A 28-year-old primipara who for several years had been taking phenytoin and carbamazepine as anticonvulsant treatment was found to have a raised serum $\alpha$-fetoprotein concentration at the 20 th week of pregnancy $(183 \mu \mathrm{g} / \mathrm{l})$. Ultrasonography during the 23rd week suggested that the fetus had anencephaly. Amniotic fluid sampled by amniocentesis yielded an $\alpha$-fetoprotein concentration of $56.3 \mathrm{mg} / 1$ which was over 50 standard deviations above the expected mean for that week; total cell count was $210 \times 10^{6} / 1$. For cell cultures about 2000 cells from the amniotic fluid were inoculated into tissue-culture dishes with small coverslips. After 24 hours the cells were fixed in $-20^{\circ} \mathrm{C}$ methanol for 30 minutes, dried in air, and examined by phase-contrast microscopy and indirect immunofluorescence microscopy, using a glial-cell specific, glial fibrillary acidic protein antiserum (anti-GFA). ${ }^{6}$ The cells were also stained with an antiserum against purified human epidermal keratin polypeptides raised in rabbits and affinity-purified in a keratin-sepharose GL4B column.

\section{Results}

Several types of cells with different morphology were seen on the coverslips after 24 hours in culture, but the glial-specific fluorescence was evident in only a proportion of the cells (figure $(b, d)$ ). The cells showing glial-specific staining were either long bipolar cells, filamentous pseudopodial cells, large vacuolated cells with inclusions, or giant cells with multiple nuclei. ${ }^{3}$ The cells that were negative after anti-GFA staining were morphologically similar to cells in normal amniotic fluid cultures, being either fibroblastoid (figure $(c)$ ) or showing keratin-specific fluorescence on immunofluorescence staining (figure $(f)$ ), a property typical of various epithelial cells. ${ }^{8}$ Severa 24-hour cell cultures from amniotic fluid samples taken from normal pregnancies for karyotype testing showed no glial-specific fluorescence.

Raised $\alpha$-fetoprotein concentrations, the findings on ultrasonography, and the presence of RA cells strongly suggested that the fetus had anencephaly. At 24 weeks the mother was delivered of a stillborn infant with typical anencephaly. Necropsy showed a large defect in the cranial end of the neural tube, permitting direct contact between spinal and amniotic cavities.

\section{Discussion}

These results suggest that the RA cells in amniotic fluid from a pregnancy complicated by fetal anencephaly are glial cells, originating from the central nervous system. We found no such cells in several normal pregnancies. The indirect immunofluorescence method with a glial-specific antiserum used in our study is highly specific for glial cells. ${ }^{6}$ ? Interestingly, related results suggesting the neural origin of RA cells were reported by Sarkar et al. ${ }^{9}$ They used a different cellular marker in immunofluorescence in a pregnancy that retrospectively resulted in an anencephalic fetus. 

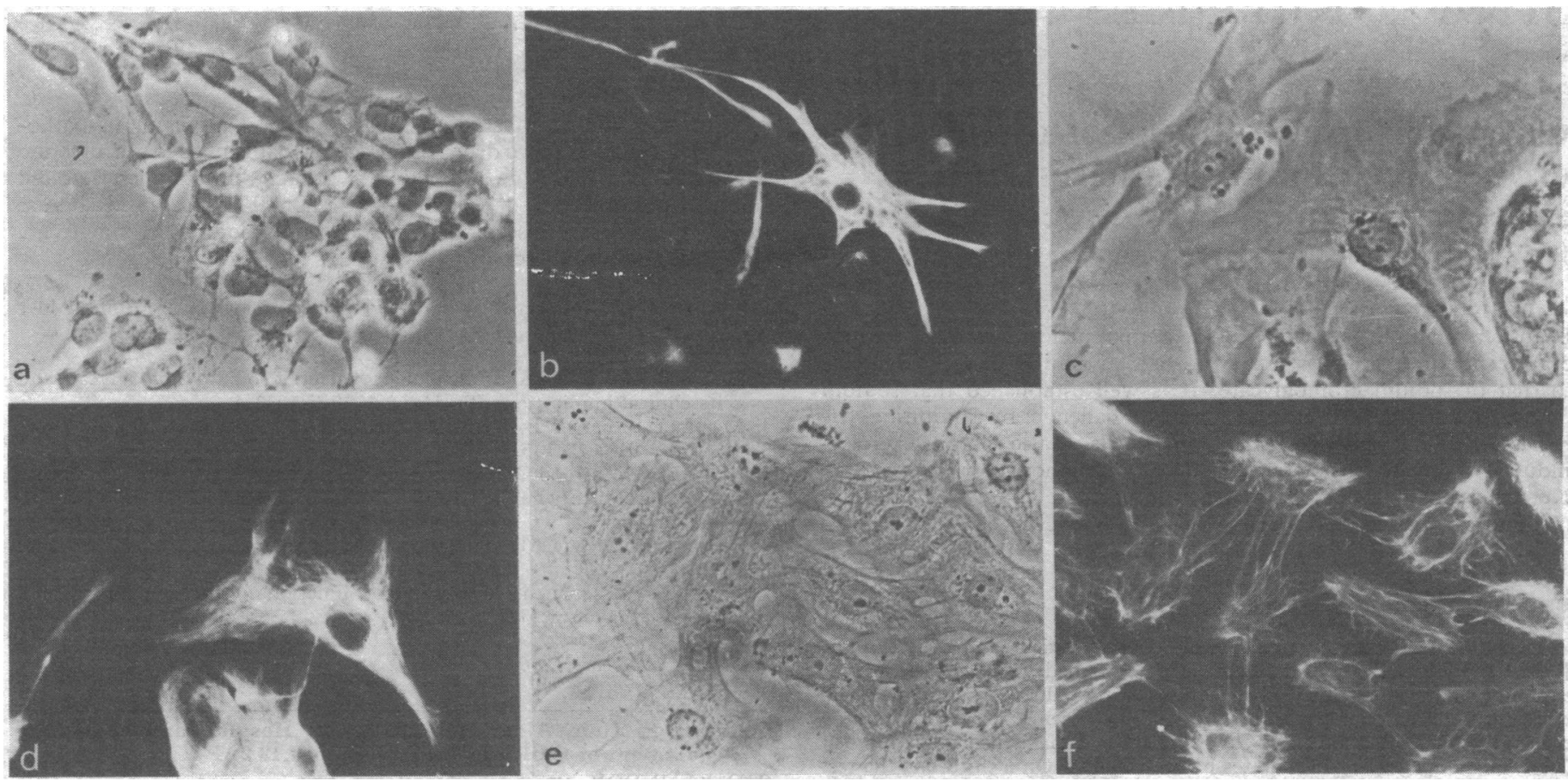

Phase-contrast $(a, c, e)$ and immunofluorescence micrographs $(b, d, f)$ of same cells cultured from amniotic fluid in pregnancy complicated by fetal anencephaly. Bright cytoplasmic fluorescence occurred after staining with anti-GFA in one filamentous cell (b). Lack of staining occurred in other cells. In $d$ cytoplasmic GFA-specific fluorescence is distinctly fibrillar. Lack of fluorescence occurred in fibroblastoid cell. Epithelioid cells from same cultures in $f$ show bright fibrillar keratin-specific fluorescence but lack GFA-specific labelling. $a, b \times 400 ; c-f \times 700$ (original magnification).

RA cells of different morphology are also present in amniotic fluid from pregnancies with other fetal abnormalities, such as exomphalos and urogenital atresia. ${ }^{4}$ In such cases tissue-specific immunofluorescence techniques may be of great value in distinguishing between the various types of malformations. Accurate fetal diagnosis should always be sought before deciding whether to terminate or continue a pregnancy complicated by raised $\alpha$-fetoprotein concentrations in maternal serum or amniotic fluid, or both. With the widespread use of maternal serum $\alpha$-fetoprotein assay for screening large populations of mothers, such cases are likely to become increasingly common. Fractionation of $\alpha$-fetoprotein ${ }^{10}$ and assay of amniotic fluid acetylcholinesterase ${ }^{11}$ have been proposed for the same purpose.

The heterogeneity of fetal cells in the amniotic fluid during the second trimester is well established, though the classification of the various cell types is still based only on arbitrary morphological criteria.12 Immunofluorescence techniques with highly specific antisera against tissue-specific cytoskeleton or cellmembrane proteins may provide a more accurate method for the characterisation and identification of amniotic fluid cell types.

This study was supported by grants from the Association of the Finnish Life Insurance Companies and Medical Research Council, Academy of Finland.

\section{References}

1 Sutherland GR, Brock DJH, Scrimgeour JB. Amniotic fluid macrophages and anencephaly. Lancet 1973 ;ii:1098-9.

2 Gosden CM, Brock DJH. Morphology of rapidly adhering amniotic-fluid cells as an aid to the diagnosis of neural-tube defects. Lancet 1977 ; : 919-22.

3 Gosden CM, Brock DJH. Amniotic fluid cell morphology in early antenatal prediction of abortion and low birth weight. $B r$ Med $\mathcal{f}$ 1978;ii:1186-9.

4 Gosden CM, Brock DJH, Eason P. The origin of the rapidly adhering cells found in amniotic fluids from foetuses with neural tube defects. Clin Genet 1977;12:193-201.

5 Ruoslahti E, Seppala M. Studies of carcino-fetal proteins: physical and chemical properties of human alpha-fetoprotein. Int $\mathcal{f}$ Cancer $1971 ; 8$ : 374-83.
6 Bignami A, Dahl D. Specificity of the glial fibrillary acidic protein for astroglia. $\mathcal{F}$ Histochem Cytochem $1977 ; 25: 466-9$.

7 Paetau A, Virtanen I, Stenman S, et al. Glial fibrillary acidic protein and intermediate filaments in human glioma cells. Acta Neuropathol $1979 ; 47: 71-4$

${ }^{8}$ Sun T-T, Green H. Immunofluorescent staining of keratin fibers in cultured cells. Cell 1978;14:469-76.

- Sarkar S, Chang HC, Porreco RP, Jones OW. Neural origin of cells in amniotic fluid. Am F Obstet Gynecol 1978;136:67-72.

${ }^{10}$ Ruoslahti E, Pekkala A, Comings E, Seppala M. Determination of subfractions of amniotic fluid alpha-fetoprotein in diagnosing spina bifida and congenital nephrosis $\mathrm{Br} \mathrm{Med} \mathcal{F}$ 1979;ii :768-9.

11 Smith AD, Wald NJ, Cuckle HS, Stirrat GM, Bobrow M, Lagercrantz H. Amniotic fluid acetylcholinesterase as a possible diagnostic test for neural-tube defects in early pregnancy. Lancet $1979 ; \mathrm{i}: 685-8$.

12 Hoehn H, Bryant EM, Karp LE, Martin MM. Cultivated cells from diagnostic amniocentesis in second trimester pregnancies. Clonal morphology and growth potential. Pediat Res 1974;8:746-54.

(Accepted 15 October 1980)

ONE HUNDRED YEARS AGO An important illustration of the way in which small-pox may be spread by postmen came before the Lambeth Vestry at its last meeting. The matter was brought before the vestry by the Sanitary Committee on the report of the medical officer, who, visiting a case of small-pox, discovered that the husband of the patient, a letter-carrier, was pursuing his official duties, whilst at the same time acting as nurse to his wife. Some linen had also been received by the wife from some neighbours to be washed, without any intimation that there was small-pox in the house, the result being that two children took the infection. After some discussion as to the best course to be adopted in dealing with the matter, it was agreed that a letter be sent to the man, pointing out that he had rendered himself liable to be prosecuted. We cannot help thinking that the recommendation of one of the members of the vestry, that the superintendent postmaster of the district should be made aware of the facts, was the right course to pursue in the interest of the public health. (British Medical fournal, 1880.) 